Pak. j. sci. ind. res. Ser. A: phys. sci. 2021 64A(3) 195-205

\title{
Central Composite Design Based Adsorption Study of Malachite Green Dye Using Reduced Graphene Oxide Nano-Adsorbent
}

\author{
Abdul Rauf Shah, Hajira Tahir* and Hafiz Muhammad Kifayatullah \\ Department of Chemistry, University of Karachi, Karachi-75270, Pakistan
}

(received November 4, 2019; revised November 11, 2020; accepted November 18, 2020)

\begin{abstract}
The adsorption of Malachite Green (MG) dye was well studied and elucidated from the liquid phase using reduced Graphene Oxide (rGO) nano-adsorbent. The desired levels of the factors were determined to be the amount of adsorbent of $0.2 \mathrm{~g} / \mathrm{L}, \mathrm{pH}$ of 8.5 , the concentration of the dye as $100 \mathrm{mg} / \mathrm{L}$ and the sonication time of $50 \mathrm{~min}$ by Central Composite Design (CCD). The removal of the dye was found to be $95 \%$ at the optimum levels of the variables. Furthermore, the removal of the dye was higher at the higher values of the amount of adsorbent and $\mathrm{pH}$. Langmuir and Temkin models were observed significant for rGO-MG dye system. The values of Gibb's free energy, the entropy and the enthalpy were found to be $-10.502 \mathrm{KJ} / \mathrm{mol}, 34.314 \mathrm{KJ} / \mathrm{mol}$ and $0.147 \mathrm{KJ} / \mathrm{mol} . \mathrm{K}$, respectively. The kinetic data were also found well fitted to pseudo second order kinetics model for the said system. Afterwards, the cost of the process was found to be US $\$ 0.654 / \mathrm{dm}^{3}$. Therefore, the adsorption process effectively removed the dye from the simulated aqueous phase using rGO nano-adsorbent.
\end{abstract}

Keywords: malachite green, reduced graphene oxide, central composite design, cost analysis, FTIR, SEM

\section{Introduction}

The rapid decrease in the reservoirs of fresh drinking water has made wastewater treatment a matter of global concern. Textile, food and electroplating factories are releasing toxic coloured effluents into the reservoirs and thereby it is a principle environmental subject matter to obviate contaminants from the aqueous phases. Textile dyeing effluents having the mixture of various organic and inorganic substances i.e dyes, bases, acids. These effluents cause several severe diseases. They also causes cancer in humans. Therefore, these effluents containing noxious dyes must be pre-treated before discharging (Robati et al., 2016; Fu et al., 2015; Gupta et al., 2013; Shahid and Mohammad, 2013; Yu and Fugetsu, 2010).

MG dye is utilized as a dyestuff. It is used to colour leather, paper and silk. It affects the aquatic ecosystem (Schmidt et al., 2018; Wang et al., 2016). The noxious dye has been treated by using biological, coagulation, adsorption, and photocatalytic processes etc (Wang and Zhao, 2016; Gautam et al., 2015; Liu et al., 2014; Suchithra et al., 2012). Adsorption has been proved as an effective, fast and simplest method. It also gives a high removal efficiency of dyes (Kundakci et al., 2011).

The current work is related to the removal of MG dye using rGO nano-adsorbent. The adsorption of the dye

*Author for correspondence; E-mail: hajirat@uok.edu.pk is endothermic which is determined by the negative value of Gibb's free energy.

\section{Materials and Methods}

Materials. Graphite powder, $\mathrm{KMnO}_{4}, 98 \% \mathrm{H}_{2} \mathrm{SO}_{4}, 30 \%$ $\mathrm{H}_{2} \mathrm{O}_{2}, 35 \% \mathrm{HCl}$, ethanol and ascorbic acids were of analytical grade. Solutions were prepared using distilled water.

Synthesis of reduced graphene oxide. Ascorbic acid of $3 \mathrm{mg} / \mathrm{mL}$ was added to $20 \mathrm{~mL}$ portion of the suspension of graphene oxide $(0.1 \mathrm{mg} / \mathrm{mL})$. The suspension was kept at $80^{\circ} \mathrm{C}$ for $12 \mathrm{~h}$. Ultrasonic irradiation of the suspension was continued for $30 \mathrm{~min}$ and also stirred throughout the process. Consequently, an aggregated freely homogenous yield of $\mathrm{rGO}$ was obtained. The centrifugation of the product was carried out at 14,500 for half hr to get solid rGO. The substance was washed with warmed water and also with ethanol to remove by-products of the reaction. The product was centrifuged again and the supernatant was obviated. Eventually, the rGO yield was desiccated in a vacuum oven at $45^{\circ} \mathrm{C}$ (Karadag and Üzüm, 2012).

Batch adsorption study. To perform batch adsorption experiments, about $0.1 \mathrm{~g}$ of $\mathrm{MG}$ dye in $1000 \mathrm{~mL}$ of distilled water was dissolved to prepare a stock solution. The experimental trials were found by using CCD 
model. A $50 \mathrm{~mL}$ solution of the dye was taken into 100 $\mathrm{mL}$ flask and other factors were maintained according to the designed runs. After the specified interval of time, the samples were filtered and analyzed at a wavelength of $618 \mathrm{~nm}$. The dye removal was computed by the subsequent formula.

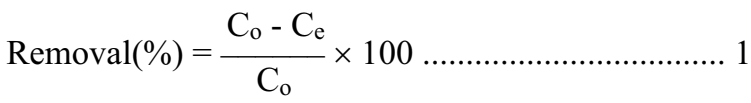

The initial dye concentration $(\mathrm{mg} / \mathrm{L})$ is $\mathrm{C}_{\mathrm{o}}$ and the equilibrium concentration $(\mathrm{mg} / \mathrm{L})$ is $\mathrm{C}_{\mathrm{e}}$, respectively (Vu et al., 2015). Dye adsorption capacity (qe) was calculated during kinetics and isotherm study by using the following equation and the volume of a solution is $\mathrm{V}(\mathrm{L})$, the amount of adsorbent is $\mathrm{W}(\mathrm{g})$ (Namasivayam and Kavitha,2002).

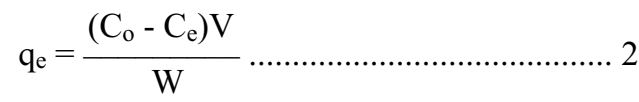

Response surface methodology (RSM). RSM is applied to improve and optimize a process which is based on mathematical and statistical techniques. In this work, four factors were optimized based on CCD with five levels. The purpose of the experimental design and analysis was to select the optimum levels of the factors to optimize the dye removal using rGO nano-adsorbent. Data were analyzed using Minitab 17 software. The dependent variable $\mathrm{Yi}$ is shown in response surface analysis by second order mathematical model as follows:

$\mathrm{Y}=\beta_{\mathrm{o}}+\Sigma_{\mathrm{i}=\mathrm{i}}^{4} \beta_{\mathrm{i}} \mathrm{x}_{\mathrm{i}}+\Sigma_{\mathrm{i}=\mathrm{i}}^{4} \Sigma_{\mathrm{j}=1}^{4} \beta_{\mathrm{ij}} \mathrm{x}_{\mathrm{i}} \mathrm{x}_{\mathrm{j}}+\sum_{\mathrm{i}=1}^{4} \beta_{\mathrm{ii}} \mathrm{x}_{\mathrm{i}}^{2} \ldots . .3$

$\beta_{\mathrm{o}}$ is constant, $\beta_{\mathrm{i}}$ is the linear term, $\beta_{\mathrm{ij}}$ is the interaction coefficient, $\beta_{\mathrm{ii}}$ is the quadratic term and $\mathrm{Y}_{\mathrm{i}}$ is percent removal of dye (Shah et al.,2017; Ghaedi et al., 2015).

\section{Results and Discussions}

Characterization of rGO. X-ray diffraction (XRD), Fourier Transform Infrared Spectroscopy (FTIR) and Scanning Electron Microscopy (SEM) were utilized to get the structural and morphological information regarding rGO nano-substance. FTIR and SEM analysis revealed the occurrence of microstructures on the textural surface of the synthesized nano-adsorbents. The Fig.3, 4, 5 are showing spectroscopic images.

Influence of sonication time. The influence of sonication time was studied ranging from 50 to $150 \mathrm{~min}$ on the removal of MG dye. An optimum level of sonication was encountered $50 \mathrm{~min}$. The influence of sonication time with other factors on the obviation of MG dye is graphed in Fig. 2.

Influence of $\mathbf{p H}$. The removal efficiency of the adsorption process was affected by the $\mathrm{pH}$ of the solution. The adsorption of MG dye was greater in the basic liquid phase which was owing to the attraction between the dye molecules and the adsorption sites of an adsorbent. The desired level of $\mathrm{pH}$ was observed 8.5 for an optimum removal of the dye. The interaction of $\mathrm{pH}$ with other process variables on the removal of the dye is shown in Fig. 2.

Influence of the amount of adsorbent. The amount of adsorbent greatly changed the removal efficiency of MG dye. At a high amount, it provided more adsorption sites to the molecules and increased the obviation of the dye. The dye removal was greater at the optimum level of $0.2 \mathrm{~g} / \mathrm{L}$ of the amount of the adsorbent. The effect of the amount of the adsorbent is shown in Fig. 2.

Influence of dye concentration. The desired level of concentration of the dye was found as $100 \mathrm{mg} / \mathrm{L}$. At high levels of dye concentration, the elimination of the dye was lower because the increased number of molecules required more active sites for adsorption. The impacts of the factor on the dye removal are plotted in Fig. 2.

Adsorption kinetics study. In the adsorption process, the value of parameters like adsorption capacity plays a vital role in finding the amount of adsorbed that can be removed by the unit mass of an adsorbent. The surface area of an adsorbent also informs us about its removal efficiency of an impurity. The high adsorption capacity and providing high surface area by an adsorbent not merely responsible for the rapid noxious dye removal but also another feature like kinetics controls the effectiveness of the process to clean dye from wastewater. Therefore, the study constraints to find the kinetics of the process (Shah et al., 2017; Gautam et al., 2014). The pseudo-first order and second order kinetics are formulated as:

$$
\begin{aligned}
& \ln \left(\mathrm{q}_{\mathrm{e}}-\mathrm{q}_{\mathrm{t}}\right)=\ln \mathrm{q}_{\mathrm{t}}-\mathrm{k}_{1} \mathrm{t} \ldots \ldots \ldots \ldots \ldots \ldots \ldots \ldots \ldots \ldots \ldots \ldots \ldots \ldots \ldots \ldots \ldots \ldots \ldots \ldots \ldots \ldots \ldots \ldots \ldots \ldots \ldots \ldots \\
& \mathrm{q}
\end{aligned}
$$

eqt $(\mathrm{mg} / \mathrm{g})$ is the amount of dye adsorbed at time $\mathrm{t}$ and $\mathrm{qe}(\mathrm{mg} / \mathrm{g})$ is the amount of dye adsorbed at equilibrium, 
respectively (Gautam et al., 2013; Shahmiri et al., 2013). The rate constant $\mathrm{K}_{\mathrm{id}}$ for the intra-particle diffusion model is found by the subsequent equation:

$$
\mathrm{q}_{\mathrm{t}}=\mathrm{K}_{\mathrm{id}} \mathrm{t}^{0.5}+\mathrm{C}
$$

Data of C intercept tell the thickness of the boundary layer. If the line of plot between $\mathrm{qt}$ and $\mathrm{t}^{1 / 2}$ passes through the origin then the rate-limiting step will be intra- particle diffusion (Ghaedi et al., 2018; Shahmiri et al., 2013). The Elovich model is given as:

$$
\mathrm{q}_{\mathrm{t}}=\frac{1}{\mathrm{~b}} \ln \mathrm{ab}+\frac{1}{\mathrm{~b}} \ln \mathrm{t}
$$

whereas, $a$ is the initial sorption rate $\mathrm{mg} / \mathrm{g} / \mathrm{min}$ and $1 / \mathrm{b}$ is the extent of surface coverage $(\mathrm{g} / \mathrm{mg}$ ) (Vadivelan and Kumar, 2005).
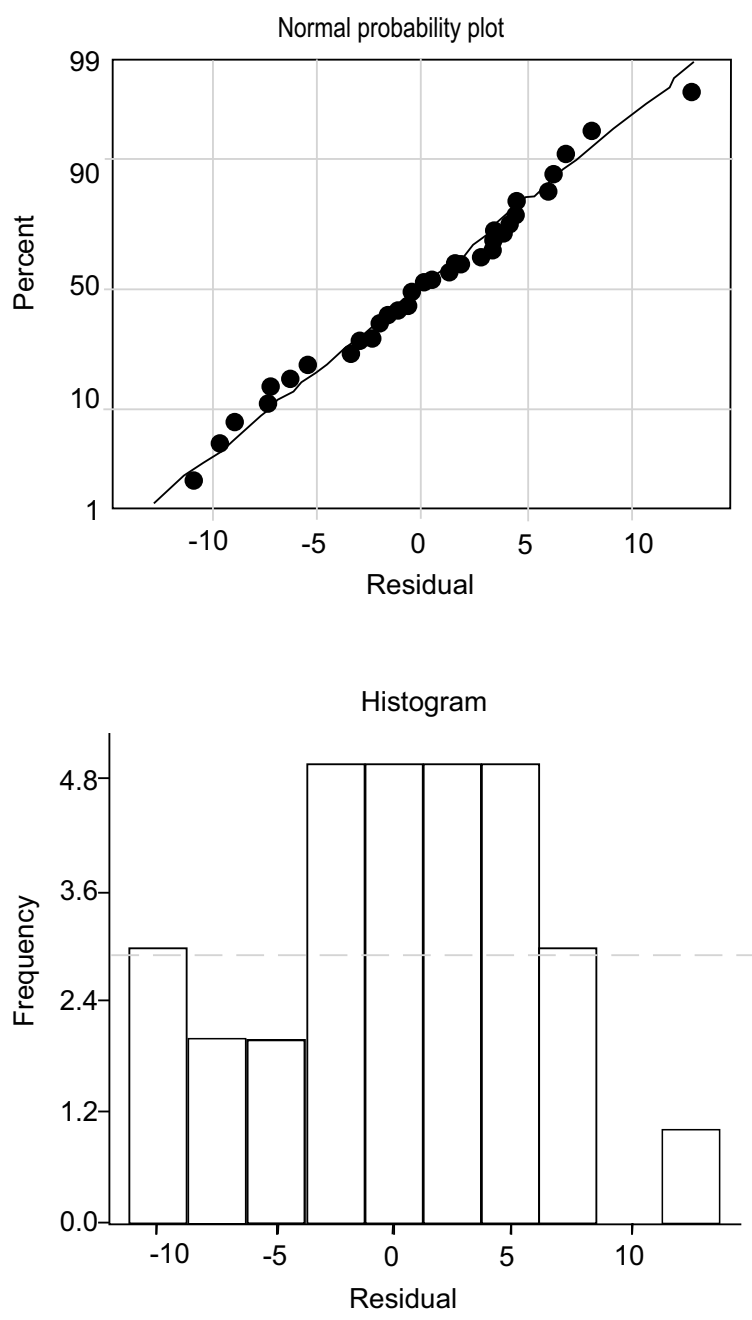

The kinetic data are presented in Table 3 showing that the adsorption of MG over rGO surface is obeying the pseudo second order kinetics model.

Thermodynamics study. The thermodynamic parameters such as enthalpy $\left.\Delta \mathrm{H}^{\circ}\right)$, Gibb's free energy change $\Delta H^{\circ}$ and entropy $\left(\Delta S^{\circ}\right)$ were analyzed by means of the following equations:

$$
\begin{aligned}
& \Delta \mathrm{G}^{\circ}=-\mathrm{RT} \ln \mathrm{Kc} \ldots \ldots \ldots \ldots \ldots \ldots \ldots \ldots \ldots \ldots \ldots
\end{aligned}
$$

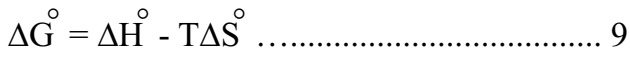

where:

$\mathrm{Kc}$ is the distribution constant for adsorption. The values of thermodynamic parameters are tabulated in Table 1 , 2. The negative values of $\Delta \mathrm{G}^{\circ}$ are indicating the spontaneous nature of MG adsorption onto the surface
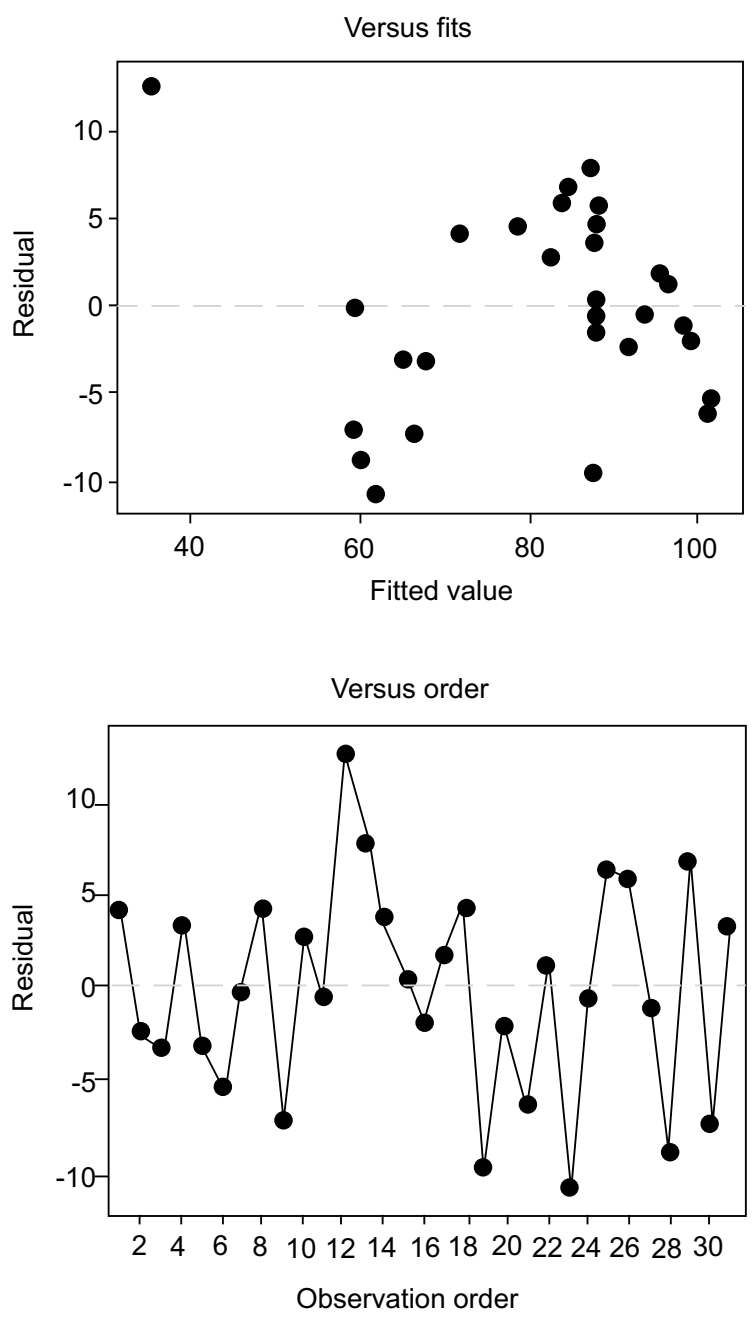

Fig. 1. Residual plots for \% MGremoval. 
Table 1. Isotherm study

\begin{tabular}{lllll}
\hline \hline \multirow{2}{*}{ Isotherm model } & Parameters & \multicolumn{3}{c}{ Temperature (K) } \\
\cline { 3 - 5 } Freundlich & $\mathrm{n}(\mathrm{mg} / \mathrm{g})$ & 2.6371 & 3.088 & 4.2087 \\
& $\mathrm{Kf}(\mathrm{g} / \mathrm{L})$ & 216.35 & 251.087 & 321.21 \\
& $\mathrm{R}^{2}$ & 0.9692 & 0.9523 & 0.9400 \\
Langmuir & $\mathrm{qm}(\mathrm{mg} / \mathrm{g})$ & 714 & 714 & 625 \\
& $\mathrm{~B}(\mathrm{~L} / \mathrm{mg})$ & 0.2456 & 0.3111 & 0.666 \\
\multirow{5}{*}{ Temkin } & $\mathrm{R}^{2}$ & 0.9964 & 0.9965 & 0.9976 \\
& $\mathrm{~B}_{1}=\mathrm{RT} / \mathrm{B}$ & 173.19 & 149.1 & 110.6 \\
& $\mathrm{KT}_{\mathrm{T}}(\mathrm{L} / \mathrm{mg})$ & 1.990 & 3.45 & 14.5 \\
& $\mathrm{R}^{2}$ & 0.9814 & 0.9701 & 0.9490 \\
\hline \hline
\end{tabular}

Table 2. Thermodynamics parameters

\begin{tabular}{llll}
\hline \hline Temperature $(\mathrm{K})$ & $\Delta \mathrm{G}(\mathrm{KJ} / \mathrm{mol})$ & $\Delta \mathrm{H}(\mathrm{KJ} / \mathrm{mol})$ & $\Delta \mathrm{S}(\mathrm{KJ} / \mathrm{mol} . \mathrm{K})$ \\
\hline $303 \mathrm{~K}$ & -10.502 & - & - \\
$308 \mathrm{~K}$ & -10.982 & 34.314 & 0.147 \\
$313 \mathrm{~K}$ & -12.0513 & - & - \\
\hline \hline
\end{tabular}

Table 3. Kinetics data

\begin{tabular}{lll}
\hline \hline Kinetic model & Parameters & Values \\
\hline Pseudo first order model & $\mathrm{q}_{\mathrm{e}}(\mathrm{mg} / \mathrm{g})$ & 464 \\
& $\mathrm{~K}_{1}$ & 0.0824 \\
& $\mathrm{R}^{2}$ & 0.9109 \\
Pseudo second order model & $\mathrm{q}_{\mathrm{e}}(\mathrm{mg} / \mathrm{g})$ & 588 \\
& $\mathrm{~K}_{2}$ & $1.806 \times 10^{-4}$ \\
& $\mathrm{R}^{2}$ & 0.9918 \\
Intra particle diffusion model & $\mathrm{K}_{\mathrm{id}}$ & 46.611 \\
& $\mathrm{C}_{\mathrm{i}}$ & 167.17 \\
& $\mathrm{R}^{2}$ & 0.9324 \\
& $\mathrm{a}(\mathrm{mg} / \mathrm{g} / \mathrm{min})$ & 169.04 \\
Elovich model & $\mathrm{b}(\mathrm{g} / \mathrm{mg})$ & $8.77 \times 10^{-3}$ \\
& $\mathrm{R}^{2}$ & 0.9566 \\
\hline \hline
\end{tabular}

Table 4. Levels of independent variables

\begin{tabular}{llllll}
\hline \hline Symbols with codes & $-\alpha$ & -1 & 0 & +1 & $+\alpha$ \\
\hline Amount of adsorbent $(\mathrm{g})=\mathrm{A}$ & 0.1 & 0.325 & 0.55 & 0.775 & 1 \\
$\mathrm{pH}=\mathrm{B}$ & 3.7 & 5.025 & 6.35 & 7.675 & 9 \\
Sonication time (min)=C & 50 & 75 & 100 & 125 & 150 \\
Dye concentration $(\mathrm{mg} / \mathrm{L})=\mathrm{D}$ & 50 & 87.5 & 125 & 162.5 & 200 \\
\hline \hline
\end{tabular}

of rGO at all temperatures. The adsorption of the dye on the rGO surface is endothermic. It is confirmed from the positive value of entropy. The nano-adsorbent is reflecting affinity to $\mathrm{MG}$ dye. It is clear from the positive value of entropy, reflecting increased entropy at the solid-solution interface during the process (Liu and Liu, 2008).

Data analysis. The treatments with the response are given in Table 4 and 5 . The obtained regression equation for the removal of MG dye is known as follow:

The percent removal of $\mathrm{MG}=-103.6+53.3 \mathrm{~B}-0.099 \mathrm{D}-$ $50.1 \mathrm{~A}+0.045 \mathrm{C}-2.912 \mathrm{~B}^{2}-0.00052 \mathrm{D}^{2}-31.8 \mathrm{~A}^{2}-0.00058 \mathrm{C}^{2}-$ $0.0113 \mathrm{~B} \times \mathrm{D}+2.73 \mathrm{~B} \times \mathrm{A}-0.0434 \mathrm{~B} \times \mathrm{C}+0.259 \mathrm{D} \times \mathrm{A}+$ $0.00127 \mathrm{D} \times \mathrm{C}+0.411 \mathrm{~A} \times \mathrm{C}$ 10

Table 5. Experimental runs with responses

\begin{tabular}{|c|c|c|c|c|}
\hline $\mathrm{pH}$ & $\begin{array}{l}\text { Dye } \\
(\mathrm{mg} / \mathrm{L})\end{array}$ & $\begin{array}{l}\text { Amount of } \\
\text { adsorbent } \\
(\mathrm{g} / \mathrm{L})\end{array}$ & $\begin{array}{l}\text { Sonication } \\
\text { time } \\
(\mathrm{min})\end{array}$ & $\begin{array}{l}\mathrm{MG} \\
\text { removal } \\
(\%)\end{array}$ \\
\hline 6.4 & 125 & 0.550 & 100 & 92 \\
\hline 7.7 & 162 & 0.325 & 75 & 89 \\
\hline 5.0 & 87 & 0.325 & 75 & 64 \\
\hline 6.4 & 125 & 0.550 & 100 & 91 \\
\hline 5.0 & 88 & 0.325 & 125 & 62 \\
\hline 7.7 & 88 & 0.325 & 75 & 96 \\
\hline 5.0 & 163 & 0.325 & 75 & 59 \\
\hline 6.4 & 125 & 0.100 & 100 & 83 \\
\hline 5.0 & 88 & 0.775 & 125 & 59 \\
\hline 6.4 & 200 & 0.550 & 100 & 85 \\
\hline 6.4 & 125 & 0.550 & 100 & 87 \\
\hline 3.7 & 125 & 0.550 & 100 & 48 \\
\hline 6.4 & 50 & 0.550 & 100 & 95 \\
\hline 6.4 & 125 & 0.550 & 150 & 92 \\
\hline 6.4 & 125 & 0.550 & 100 & 88 \\
\hline 6.4 & 125 & 0.550 & 100 & 86 \\
\hline 7.7 & 163 & 0.775 & 75 & 97 \\
\hline 5.0 & 163 & 0.775 & 125 & 76 \\
\hline 6.4 & 125 & 0.550 & 100 & 78 \\
\hline 9.0 & 125 & 0.550 & 100 & 97 \\
\hline 7.7 & 163 & 0.775 & 125 & 95 \\
\hline 7.7 & 88 & 0.775 & 75 & 98 \\
\hline 5.0 & 163 & 0.325 & 125 & 51 \\
\hline 7.7 & 88 & 0.325 & 125 & 93 \\
\hline 6.4 & 125 & 1.000 & 100 & 90 \\
\hline 7.7 & 163 & 0.325 & 125 & 94 \\
\hline 7.7 & 88 & 0.775 & 125 & 97 \\
\hline 5.0 & 163 & 0.775 & 75 & 51 \\
\hline 6.4 & 125 & 0.550 & 50 & 91 \\
\hline 5.0 & 88 & 0.775 & 75 & 52 \\
\hline 6.4 & 125 & 0.550 & 100 & 91 \\
\hline
\end{tabular}


(a)

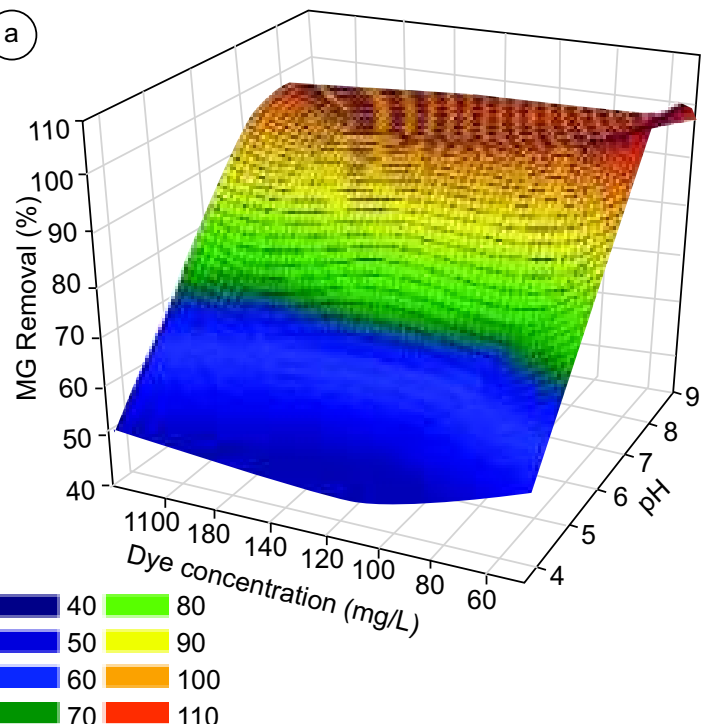

(c)

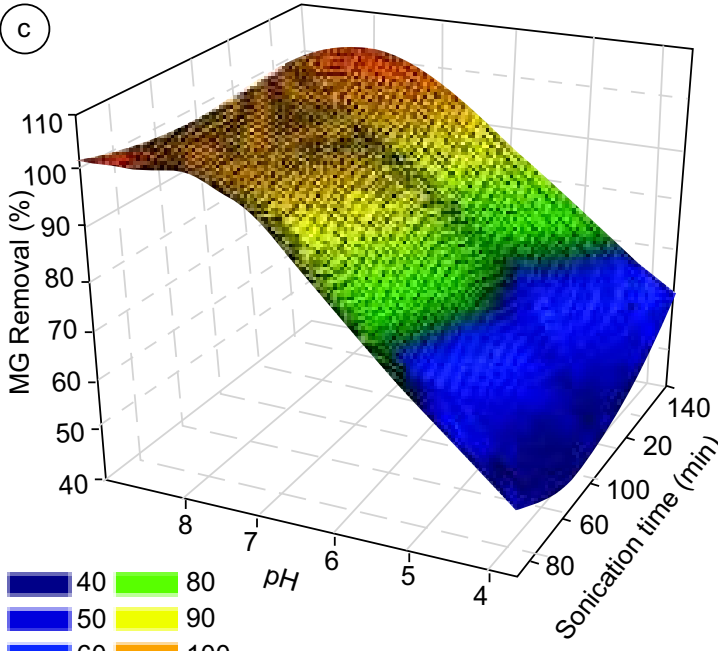

$60 \quad 100$

$70 \square 110$

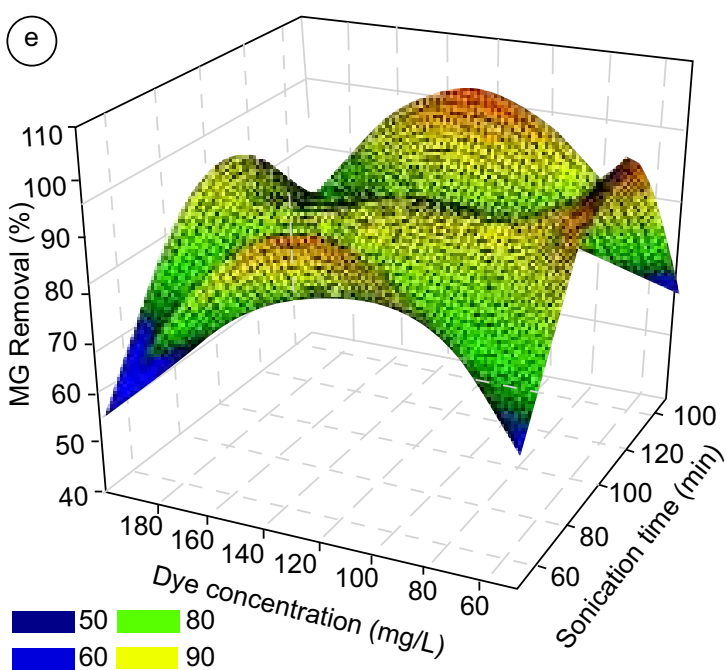

(b)

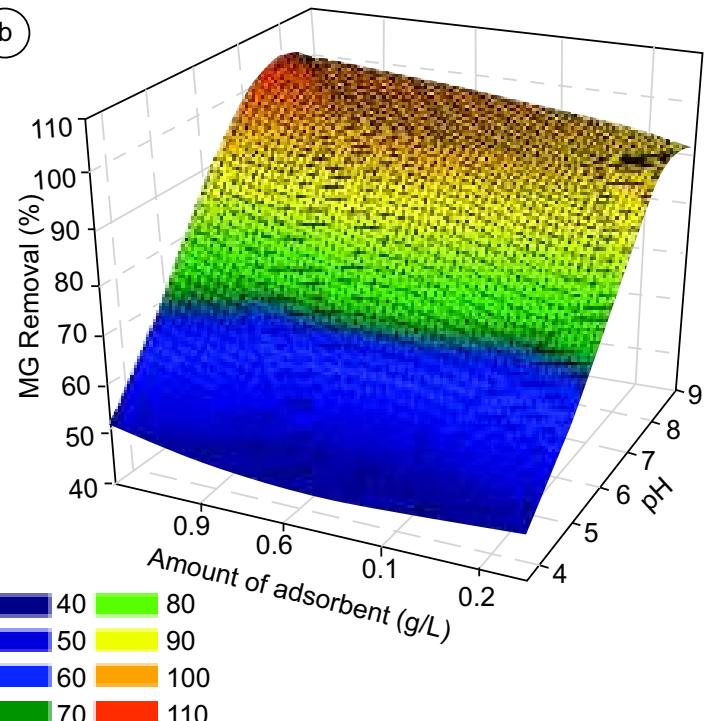

(d)
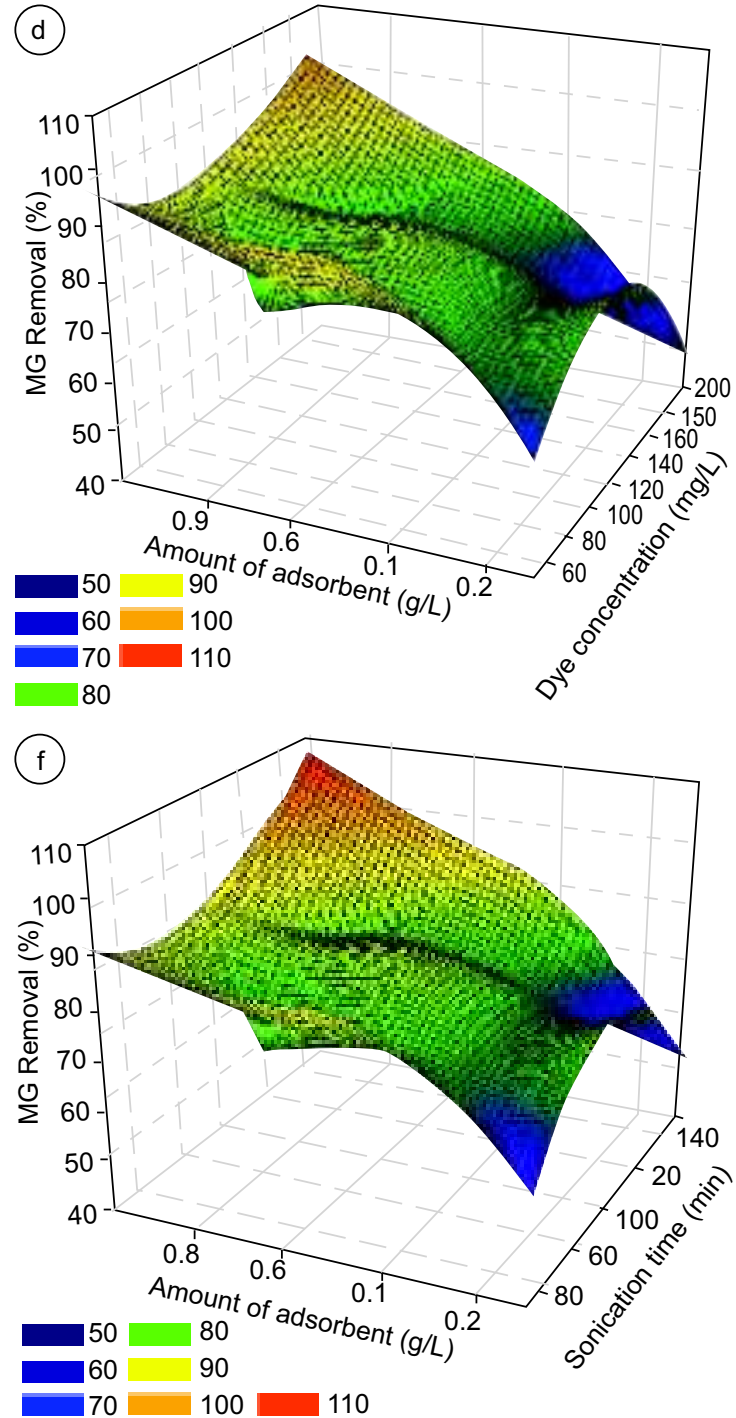

Fig. 2. Response surface plots. 
The significance of independent variables was computed on the dependent variable by ANOVA. The results are tabulated in Table 7 and 8 . The significance of the model and the factors was checked at the P-value of $5 \%$. Furthermore, the P-value of the model was found to be 0.000 , showing that the CCD model is significant and Lack of fit test proved insignificant. In addition,

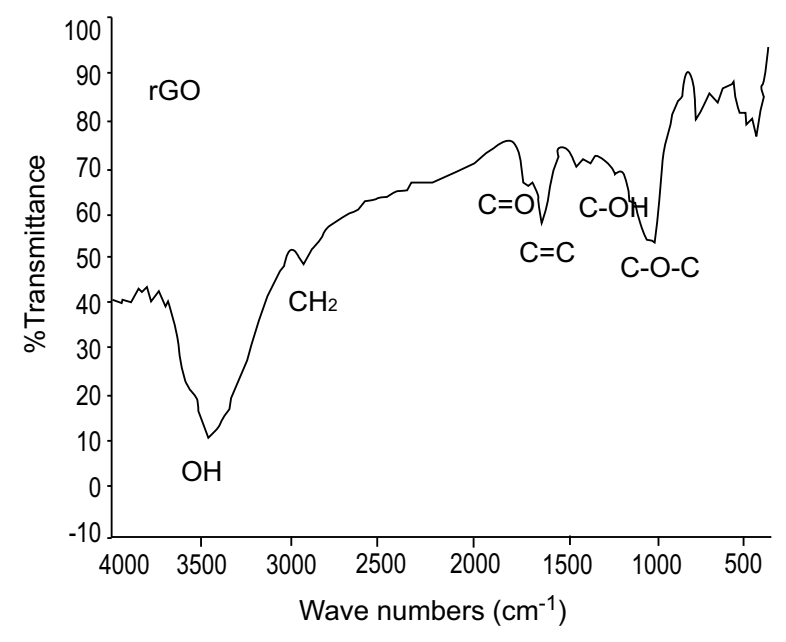

Fig. 3. FTIR spectrum.

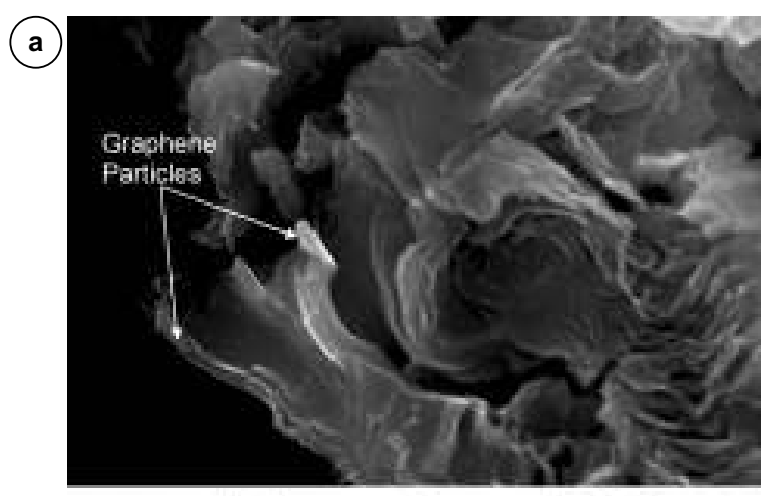

(b)

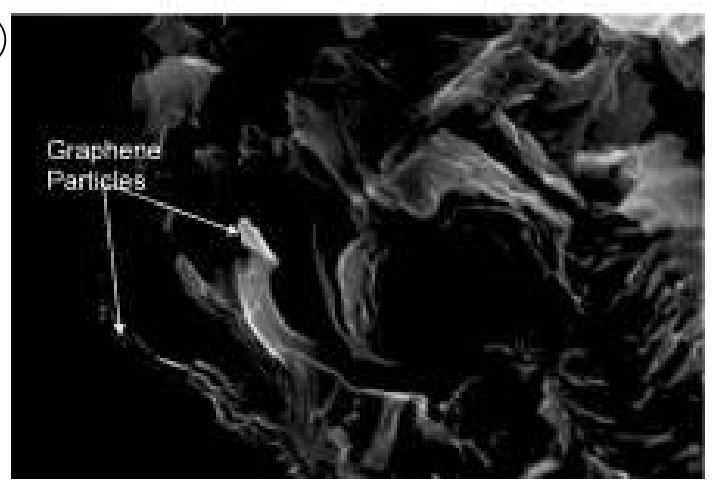

Fig. 4. SEM images of (a) rGO (b) rGO-MG.
Correlation values $\left(\mathrm{R}^{2}\right)$ was encountered to be $88.36 \%$. The model summary is given in Table 6 . The residual plots are showing the nature of the developed model (Kifayatullah et al., 2020; Crini and Badot, 2008). Fig. 1 is representing the residual plots. It is found that $\mathrm{pH}$ is showing the linear and square effect on the efficiency of adsorption method.

FTIR, SEM and XRD analysis of rGO. The FTIR spec-trum of rGO is shown in Fig. 3. The vibrational peaks at $3405 / \mathrm{cm}$ correspond to $-\mathrm{OH}, 1725 / \mathrm{cm}$ to$\mathrm{COOH}$ and $1392-1046 / \mathrm{cm}$ are related to other oxides. However, the intensity of vibration of $\mathrm{C}-\mathrm{H}$ bond of $-\mathrm{CH}_{2}$ - at 2928 and $2865 / \mathrm{cm}$ is higher owing to the formation of rGO. SEM images of $\mathrm{rGO}$ are given in Fig. 4. It is clear that rGO sheets are layered, wrinkled and entangled with each other. The Miller indices of the peak (002) at $2 \theta=24.160$ is showing rGONPs structure as given in Fig. 5.

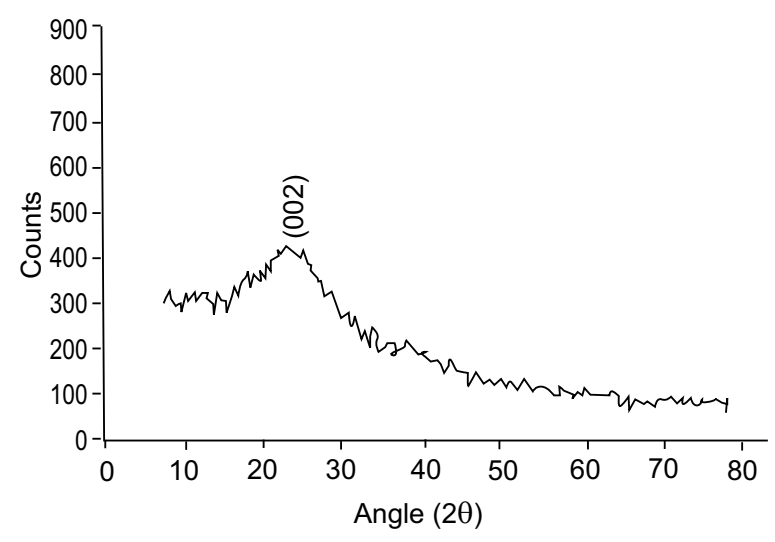

Fig. 5. XRD spectrum.

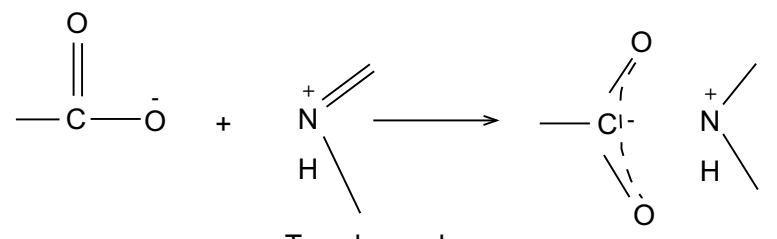

Type I complex

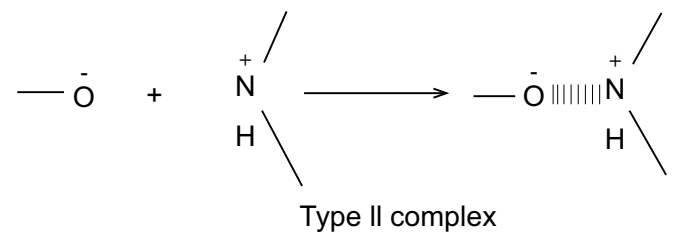

Fig. 6. Mechanism of adsorption of the dye. 
Table 6. Model Summary

\begin{tabular}{ll}
\hline \hline $\mathrm{S}$ (Root mean square error) & 7.714 \\
\hline $\mathrm{R}^{2}$ & $88.36 \%$ \\
$\mathrm{R}^{2}$ (adj) & $78.17 \%$ \\
$\mathrm{R}^{2}$ (pred) & $40.33 \%$ \\
\hline \hline
\end{tabular}

Mechanism of adsorption. MG molecule bears a positive charge. The ion is attracted towards the negative oxygen-containing functional groups present at the surface of reduced graphene oxide ( $\mathrm{rGO}$ ). The presence of unsaturation in adsorbate and adsorbent molecule generates pi-pi interaction between both molecules.

Table 7. ANOVA data

\begin{tabular}{|c|c|c|c|c|c|}
\hline Source & DF & Adj SS & Adj MS & F-Value & P-Value \\
\hline Model & 14 & 7225 & 516.1 & 8.670 & 0.000 \\
\hline Linear & 4 & 6209 & 1552 & 26.08 & 0.000 \\
\hline $\mathrm{pH}$ & 1 & 6112 & 6112 & 102.7 & 0.000 \\
\hline Dye & 1 & 35.04 & 35.04 & 0.590 & 0.454 \\
\hline Amount of adsorbent & 1 & 40.04 & 40.04 & 0.670 & 0.424 \\
\hline Sonication time & 1 & 22.04 & 22.04 & 0.370 & 0.551 \\
\hline Square & 4 & 782.9 & 195.73 & 3.290 & 0.038 \\
\hline $\mathrm{pH}^{*} \mathrm{pH}$ & 1 & 747.1 & 747.16 & 12.55 & 0.003 \\
\hline Dye*[Dye] & 1 & 15.52 & 15.52 & 0.260 & 0.617 \\
\hline Amount of adsorbent*Amount of adsorbent & 1 & 74.27 & 74.27 & 1.250 & 0.280 \\
\hline Sonication time* sonication time & 1 & 3.740 & 3.74 & 0.060 & 0.805 \\
\hline 2-Way interaction & 6 & 233.3 & 38.90 & 0.650 & 0.687 \\
\hline $\mathrm{pH} *[\mathrm{Dye}]$ & 1 & 5.060 & 5.06 & 0.090 & 0.774 \\
\hline $\mathrm{pH}^{*}$ Amount of adsorbent & 1 & 10.56 & 10.56 & 0.180 & 0.679 \\
\hline $\mathrm{pH}^{*}$ Sonication time & 1 & 33.06 & 33.06 & 0.560 & 0.467 \\
\hline [Dye $]^{*}$ Amount of adsorbent & 1 & 76.56 & 76.56 & 1.290 & 0.273 \\
\hline [Dye]*Sonication time & 1 & 22.56 & 22.56 & 0.380 & 0.547 \\
\hline Amount of adsorbent*Sonication time & 1 & 85.56 & 85.56 & 1.440 & 0.248 \\
\hline Error & 16 & 952.3 & 59.52 & & \\
\hline Lack-of-fit & 10 & 814.5 & 81.46 & 3.550 & 0.067 \\
\hline Pure error & 6 & 137.7 & 22.95 & & \\
\hline Total & 30 & 8177 & & & \\
\hline
\end{tabular}

Table 8. Student't and P-values

\begin{tabular}{|c|c|c|c|c|c|c|}
\hline Term & Effect & Coef & SE Coef & T-value & P-value & VIF \\
\hline Constant & & 87.57 & 2.92 & 30.03 & 0.000 & \\
\hline $\mathrm{pH}$ & 31.92 & 15.96 & 1.57 & 10.13 & 0.000 & 1.00 \\
\hline Dye & -2.42 & -1.21 & 1.57 & -0.77 & 0.454 & 1.00 \\
\hline Amount of adsorbent & 2.58 & 1.29 & 1.57 & 0.82 & 0.424 & 1.00 \\
\hline Sonication time & 1.92 & 0.96 & 1.57 & 0.61 & 0.551 & 1.00 \\
\hline $\mathrm{pH}^{*} \mathrm{pH}$ & -10.22 & -5.11 & 1.44 & -3.54 & 0.003 & 1.03 \\
\hline$[\text { Dye }]^{*}[\mathrm{Dye}]$ & -1.47 & -0.74 & 1.44 & -0.51 & 0.617 & 1.03 \\
\hline Amount of adsorbent*Amount of adsorbent & -3.22 & -1.61 & 1.44 & -1.12 & 0.280 & 1.03 \\
\hline Sonication Time*Sonication Time & -0.72 & -0.36 & 1.44 & -0.25 & 0.805 & 1.03 \\
\hline $\mathrm{pH} *[\mathrm{Dye}]$ & -1.13 & -0.56 & 1.93 & -0.29 & 0.774 & 1.00 \\
\hline $\mathrm{pH}^{*}$ Amount of adsorbent & 1.62 & 0.81 & 1.93 & 0.42 & 0.679 & 1.00 \\
\hline $\mathrm{pH} \mathrm{H}^{*}$ Sonication time & -2.87 & -1.44 & 1.93 & -0.75 & 0.467 & 1.00 \\
\hline$[\text { Dye }]^{*}$ Amount of adsorbent & 4.37 & 2.19 & 1.93 & 1.13 & 0.273 & 1.00 \\
\hline$[\mathrm{Dye}]^{*}$ Sonication time & 2.37 & 1.19 & 1.93 & 0.62 & 0.547 & 1.00 \\
\hline Amount of adsorbent* Sonication time & 4.63 & 2.31 & 1.93 & 1.20 & 0.248 & 1.00 \\
\hline
\end{tabular}


Table 9. The cost analysis

\begin{tabular}{llc}
\hline \hline Parameters & $\begin{array}{l}\text { Approx. } \\
\text { consumption } \\
\left(\mathrm{dm}^{3}\right)\end{array}$ & $\begin{array}{l}\text { Cost } \\
\text { (US\$) }\end{array}$ \\
\hline $\begin{array}{l}\text { Electrical energy } \\
\text { (for ultrasonication) }\end{array}$ & $0.153 \mathrm{kWh}$ & 0.020 \\
Sulphuric acid & $36 \mathrm{~mL}$ & 0.0099 \\
Hydrochloric acid $(\mathrm{HCl})$ & $4.0 \mathrm{~mL}$ & 0.0010 \\
Sodium hydroxide $\left(\mathrm{NaOH}^{2}\right)$ & $1.0 \mathrm{~g}$ & 0.0470 \\
Sodium nitrate $\left(\mathrm{NaNO}_{3}\right)$ & $0.8 \mathrm{~g}$ & 0.0143 \\
Potassium permanganate & $4.8 \mathrm{~g}$ & 0.5736 \\
(KMnO & & \\
Hydrogen peroxide $\left(\mathrm{H}_{2} \mathrm{O}_{2}\right)$ & $16 \mathrm{~mL}$ & 0.0083 \\
Graphite powder & $0.8 \mathrm{~g}$ & 0.0013 \\
MG dye & $0.1 \mathrm{~g}$ & 0.010 \\
\hline & \multicolumn{2}{c}{ Total cost=0.654 US\$ } \\
\hline
\end{tabular}

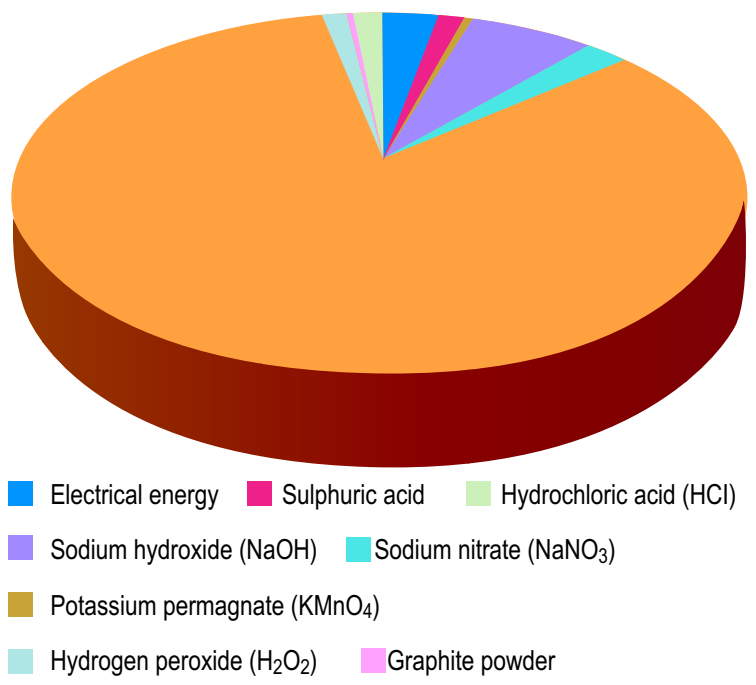

Fig. 7. Cost distribution.

Table 10. Comparison of adsorption capacities of various adsorbents

\begin{tabular}{|c|c|c|}
\hline Adsorbent & $\mathrm{qm}(\mathrm{mg} / \mathrm{g})$ & References \\
\hline Reduced graphene oxide-hematite $\left(œ-\mathrm{Fe}_{2} \mathrm{O}_{3}\right)$ & 438 & Liu et al., 2015 \\
\hline $\mathrm{ZnO}$ nanoparticles loaded activated carbon & 322 & Ghaedi et al., 2014 \\
\hline Activated carbon prepared from bamboo & 263 & Hameed and El-Khaiary, 2008 \\
\hline Graphene oxide & 248 & Bradder et al., 2010 \\
\hline Reduced graphene oxide-agarose hydrogel & 242 & Wang et al., 2013 \\
\hline Groundnut shell derived activatedcarbon & 222 & Malik et al., 2007 \\
\hline Metal-organic framework MIL-100(Fe) & 205 & Huo and Yan, 2012 \\
\hline Glutamate functionalized sawdust & 196 & Malik et al., 2007 \\
\hline Graphene oxide-agarose hydrogel & 186 & Gong et al., 2009 \\
\hline Bentonite & 178 & Bulut et al., 2008 \\
\hline Bagasse fly ash & 170 & Mall et al., 2005 \\
\hline Palm trunk fibre & 149 & Hameed and El-Khaiary, 2008 \\
\hline Activated carbon (T3K618) & 149 & Önal et al., 2007 \\
\hline Rice straw-derived char & 148 & Hameed and El-Khaiary, 2008 \\
\hline Reduced graphene oxide- $\mathrm{Fe}_{3} \mathrm{O}_{4}$ & 54.0 & Geng et al., 2012 \\
\hline $\mathrm{Fe}_{3} \mathrm{O}_{4} / \beta-\mathrm{CD} / \mathrm{GO}$ & 740 & Wang et al., 2015 \\
\hline Reduced graphene oxide & 612 & This work \\
\hline
\end{tabular}

Hydrogen bonding also promotes the adsorption of the dye molecule at the surface of the adsorbent as shown in Fig. 6 (Naderi and Ramezanzadeh, 2020; Lee et al., 2011).

\section{Comparison of adsorption capacities of adsorbents.}

The adsorption capacities of various adsorbents is given in Table 10. The cost analysis of the process is tabulated in Table 9 and shown in Fig. 7. It is clear that rGO has good adsorption capacity for the removal of MG dye by providing large surface area.

\section{Conclusion}

The removal of MG dye onto rGO surface was investigated in collectivity with the amount of adsorbent, sonication time, $\mathrm{pH}$ and dye concentration. $\mathrm{pH}$ showed a greater effect on the process. The greater turnover of the adsorption process was encountered at the basic $\mathrm{pH}$. Langmuir model well illustrated the adsorption data. The adsorption of the dye was following pseudo second order rate equation. Furthermore, the thermodynamics study revealed that the nature of the process 
was spontaneous and endothermic. The randomness of the system was also increased during the process. Therefore, rGO can be utilized as an adsorbent to remove MG from simulated and real wastewater.

\section{Acknowledgement}

The authors acknowledge the financial assistance from the Department of Chemistry, University of Karachi, Karachi, Pakistan.

Conflict of Interest. The authors declare no conflict of interest.

\section{References}

Bradder, P., Ling, S.K., Wang, S., Liu, S. 2010. Dye adsorption on layered graphite oxide. Journal of Chemical and Engineering Data, 56: 138-141.

Bulut, E., Özacar, M., Sengil, I.A. 2008. Adsorption of malachite green onto bentonite: equilibrium and kinetic studies and process design. Microporous and Mesoporous Materials, 115: 234-246.

Crini, G., Badot, P.M. 2008. Application of chitosan, a natural amino-polysaccharide, for dye removal from aqueous solutions by adsorption processes using batch studies: a review of recent literature. Progress in Polymer Science, 33: 399-447.

Fu, J., Chen, Z., Wang, M., Liu, S., Zhang, J., Zhang, J., Han, R., Xu, Q. 2015. Adsorption of methylene blue by a high-efficiency adsorbent (polydopamine microspheres): kinetics, isotherm, thermodynamics and mechanism analysis. Chemical Engineering Journal, 259: 53-61.

Gautam, R.K., Gautam, P.K., Banerjee, S., Rawat, V., Soni, S., Sharma, S.K., Chattopadhyaya, M.C. 2015. Removal of tartrazine by activated carbon biosorbents of Lantana camara: kinetics, equilibrium modeling and spectroscopic analysis. Journal of Environmental Chemical Engineering, 3: 79-88.

Gautam, P.K., Gautam, R.K., Banerjee, S., Lofrano, G., Sanroman, M.A., Chattopadhyaya, M.C., Pandey, J.D. 2015. Preparation of activated carbon from Alligator weed (Alternenthera philoxeroids) and its application for tartrazine removal: isotherm, kinetics and spectroscopic analysis. Journal of Environmental Chemical Engineering, 3: 25602568.

Gautam, R.K., Mudhoo, A., Lofrano, G., Chattopadhyaya, M.C. 2014. Biomass-derived biosorbents for metal ions sequestration: adsorbent modification and activation methods and adsorbent regeneration. Journal of Environmental Chemical Engineering, 2: 239-259.

Gautam, R.K., Mudhoo, A., Chattopadhyaya, M.C., 2013. Kinetic, equilibrium, thermodynamic studies and spectroscopic analysis of Alizarin red S removal by mustard husk. Journal of Environmental Chemical Engineering, 1: 1283-1291.

Gautam, R.K., Gautam, P.K., Banerjee, S., Soni, S., Singh, S.K., Chattopadhyaya, M.C. 2015. Removal of Ni (II) by magnetic nanoparticles. Journal of Molecular Liquids, 204: 60-69.

Ghaedi, M., Ansari, A., Assefi Nejad, P., Ghaedi, A., Vafaei, A., Habibi, M.H. 2015. Artificial neural network and bees algorithm for removal of Eosin B using cobalt oxide nanoparticle-activated carbon: Isotherm and Kinetics study. Environmental Progress \& Sustainable Energy, 34: 155-168.

Ghaedi, A.M., Ghaedi, M., Karami, P. 2015. Comparison of ultrasonic with stirrer performance for removal of sunset yellow (SY) by activated carbon prepared from wood of orange tree: Artificial neural network modeling. Spectrochimica Acta Part A: Molecular and Biomolecular Spectroscopy, 138: 789-799.

Ghaedi, A.M., Panahimehr, M., Nejad, A.R.S., Hosseini, S.J., Vafaei, A., Baneshi, M.M. 2018. Factorial experimental design for the optimization of highly selective adsorption removal of lead and copper ions using metal organic framework MOF-2 (Cd). Journal of Molecular Liquids, 272: 15-26.

Ghaedi, M., Ansari, A., Habibi, M.H., Asghari, A.R. 2014. Removal of malachite green from aqueous solution by zinc oxide nanoparticle loaded on activated carbon: kinetics and isotherm study. Journal of Industrial and Engineering Chemistry, 20: 17-28.

Gupta, V.K., Kumar, R., Nayak, A., Saleh, T.A., Barakat, M.A. 2013. Adsorptive removal of dyes from aqueous solution onto carbon nanotubes: a review. Advances in Colloid and Interface Science, 193: 24-34.

Gong, R., Feng, M., Zhao, J., Cai, W., Liu, L. 2009. Functionalization of sawdust with monosodium glutamate for enhancing its malachite green removal capacity. Bioresource Technology, 100: 975-978.

Geng, Z., Lin, Y., Yu, X., Shen, Q., Ma, L., Li, Z., Pan, N., Wang, X. 2012. Highly efficient dye adsorption and removal: a functional hybrid of reduced graphene oxide- $-\mathrm{Fe}_{3} \mathrm{O}_{4}$ nanoparticles as an easily 
regenerative adsorbent. Journal of Materials Chemistry, 22: 3527-3535.

Hameed, B.H., El-Khaiary, M.I. 2008. Malachite green adsorption by rattan sawdust: Isotherm, kinetic and mechanism modeling. Journal of Hazardous Materials, 159: 574-579.

Hameed, B.H., El-Khaiary, M.I. 2008. Equilibrium, kinetics and mechanism of malachite green adsorption on activated carbon prepared from bamboo by $\mathrm{K}_{2} \mathrm{CO}_{3}$ activation and subsequent gasification with $\mathrm{CO}_{2}$. Journal of Hazardous Materials, 157: 344-351.

Hameed, B.H., El-Khaiary, M.I. 2008. Kinetics and equilibrium studies of malachite green adsorption on rice straw-derived char. Journal of Hazardous Materials, 153: 701-708.

Huo, S.H., Yan, X.P. 2012. Metal-organic framework MIL-100 (Fe) for the adsorption of malachite green from aqueous solution. Journal of Materials Chemistry, 22: 7449-7455.

Kundakci, S., Ögüt, H.G., Üzüm, Ö.B., Karadag, E. 2011. Equilibrium swelling characterization and dye uptake studies of acrylamide-co-methylenesuccinic acid hydrogels and semi-IPNs with PEG. Polymer Plastics Technology and Engineering, 50: 947-956.

Karadag, E., Üzüm, Ö.B. 2012. A study on water and dye sorption capacities of novel ternary acrylamide/ sodium acrylate/PEG semi IPN hydrogels. Polymer Bulletin, 68: 1357-1368.

Kifayatullah, H.M., Tahir, H., Shah, A.R. 2020. Modeling and optimization of ultrasound assisted adsorption of crystal violet dye by graphene oxide nanoparticles using response surface methodology. International Journal of Environmental Analytical Chemistry, $1-17$.

Liu, A., Zhou, W., Shen, K., Liu, J., Zhang, X. 2015. One-pot hydrothermal synthesis of hematite-reduced graphene oxide composites for efficient removal of malachite green from aqueous solution. $R S C$ Advances, 5: 17336-17342.

Liu, Y., Kang, Y., Mu, B., Wang, A. 2014. Attapulgite/ bentonite interactions for methylene blue adsorption characteristics from aqueous solution. Chemical Engineering Journal, 237: 403-410.

Liu, Y., Liu, Y.J. 2008. Biosorption isotherms, kinetics and thermodynamics. Separation and Purification Technology, 61: 229-242.

Lee, D.W., Hong, T.K., Kang, D., Lee, J., Heo, M., Kim, J.Y., Kim, B.S., Shin, H.S. 2011. Highly controllable transparent and conducting thin films using layer-by-layer assembly of oppositely charged reduced graphene oxides. Journal of Materials Chemistry, 21: 3438-3442.

Namasivayam, C., Kavitha, D. 2002. Removal of Congo Red from water by adsorption onto activated carbon prepared from coir pith, an agricultural solid waste. Dyes and Pigments, 54: 47-58.

Naderi, R., Ramezanzadeh, B. 2020. Incorporation of Graphene Oxide Nanoparticles Modified with Benzimidazole into an Epoxy Polyamide Coating to Enhance the Physical-Mechanical Properties.

Malik, R., Ramteke, D.S., Wate, S.R. 2007. Adsorption of malachite green on groundnut shell waste based powdered activated carbon. Waste Management, 27: 1129-1138.

Mall, I.D., Srivastava, V.C., Agarwal, N.K., Mishra, I.M. 2005. Adsorptive removal of malachite green dye from aqueous solution by bagasse fly ash and activated carbon-kinetic study and equilibrium isotherm analyses. Colloids and Surfaces A: Physicochemical and Engineering Aspects, 264: 17-28.

Önal, Y., Akmil-Basar, C., Sarici-Özdemir, Ç. 2007. Investigation kinetics mechanisms of adsorption malachite green onto activated carbon. Journal of Hazardous Materials, 146: 194-203.

Robati, D., Rajabi, M., Moradi, O., Najafi, F., Tyagi, I., Agarwal, S., Gupta, V.K. 2016. Kinetics and thermodynamics of malachite green dye adsorption from aqueous solutions on graphene oxide and reduced graphene oxide. Journal of Molecular Liquids, 214: 259-263.

Schmidt, M., Deckwerth, J., Schomac̈ker, R., Schwarze, M. 2018. Alkaline hydrolysis of methyl decanoate in surfactant-based systems. The Journal of Organic Chemistry, 83: 7398-7406.

Shahid, M., Mohammad, F. 2013. Recent advancements in natural dye applications: a review. Journal of Cleaner Production, 53: 310-331.

Shah, A.R., Tahir, H., Ullah, H.M.K., Adnan, A. 2017. Optimization of electro-coagulation process for the removal of binary dye mixtures using response surface methodology and estimation of operating cost. Open Journal of Applied Sciences, 7: 458484.

Shah, A.R., Tahir, H., Kifayatullah, H.M. 2017. Central composite design based electro-coagulation process for the treatment of textile effluent of SITE, industrial zone of Karachi City. Desalination and 
Water Treatment, 94: 72-88.

Shahmiri, M.R., Bahari, A., Karimi-Maleh, H., Hosseinzadeh, R., Mirnia, N. 2013. Ethynylferrocene-NiO/MWCNT nanocomposite modified carbon paste electrode as a novel voltammetric sensor for simultaneous determination of glutathione and acetaminophen. Sensors and Actuators B: Chemical, 177: 70-77.

Suchithra, P.S., Vazhayal, L., Mohamed, A.P., Ananthakumar, S. 2012. Mesoporous organic-inorganic hybrid aerogels through ultrasonic assisted sol-gel intercalation of silica-PEG in bentonite for effective removal of dyes, volatile organic pollutants and petroleum products from aqueous solution. Chemical Engineering Journal, 200: 589-600.

Vadivelan, V., Kumar, K.V. 2005. Equilibrium, kinetics, mechanism, and process design for the sorption of methylene blue onto rice husk. Journal of Colloid and Interface Science, 286: 90-100.

Vu, T.H.T., Tran, T.T.T., Le, H.N.T., Nguyen, P.H.T., Bui, N.Q., Essayem, N. 2015. A new green approach for the reduction of graphene oxide nanosheets using caffeine. Bulletin of Materials Science, 38: 667-671.

Wang, N., Zhao, M. 2016. Study on Thermodynamics and kinetics of association interactions between malachite green and OP-10 in aqueous solutions. Journal of Dispersion Science and Technology, 37: 190-195.

Wang, Y., Zhang, P., Liu, C.F., Huang, C.Z. 2013. A facile and green method to fabricate graphenebased multifunctional hydrogels for miniature-scale water purification. RSC Advances, 3: 9240-9246.

Wang, D., Liu, L., Jiang, X., Yu, J., Chen, X. 2015. Adsorption and removal of malachite green from aqueous solution using magnetic $\beta$-cyclodextringraphene oxide nanocomposites as adsorbents. Colloids and Surfaces A: Physicochemical and Engineering Aspects, 466: 66-173.

Yu, H., Fugetsu, B. 2010. A novel adsorbent obtained by inserting carbon nanotubes into cavities of diatomite and applications for organic dye elimination from contaminated water. Journal of Hazardous Materials, 177: 138-145. 